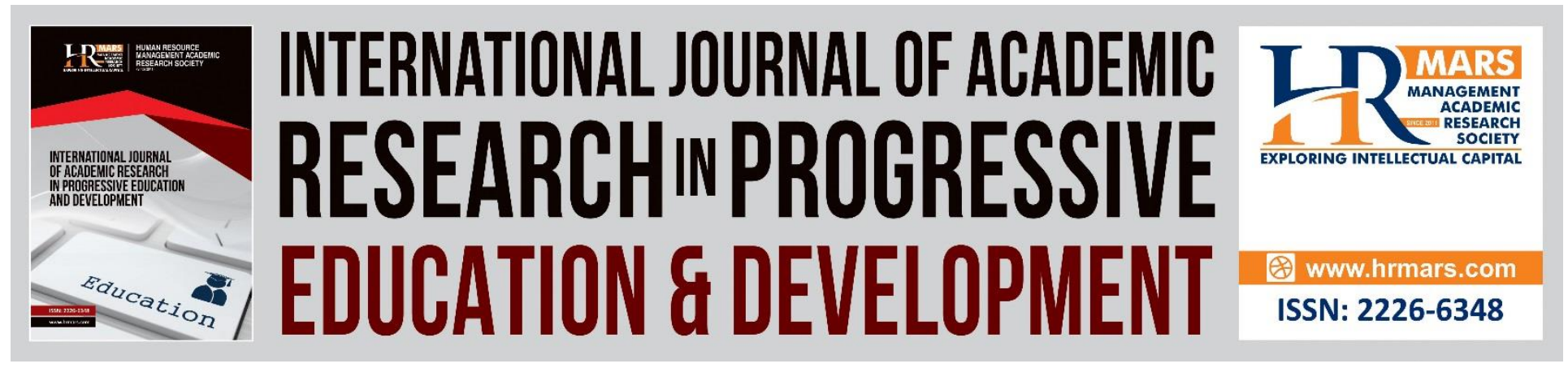

\title{
TPACK Framework Based Research in Mathematical Education: A Systematic Literature Review
}

Noraidah Othman \& Siti Mistima Maat

To Link this Article: http://dx.doi.org/10.6007/IJARPED/v9-i2/7284

DOI:10.6007/IJARPED/v9-i2/7284

Received: 25 March 2020, Revised: 27 April 2020, Accepted: 18 May 2020

Published Online: 09 June 2020

In-Text Citation: (Othman \& Maat, 2020)

To Cite this Article: Othman, N., \& Maat, S. M. (2020). TPACK Framework Based Research in Mathematical Education: A Systematic Literature Review. International Journal of Academic Research in Business and Social Sciences, 9(2), 158-171.

Copyright: (C) 2020 The Author(s)

Published by Human Resource Management Academic Research Society (www.hrmars.com)

This article is published under the Creative Commons Attribution (CC BY 4.0) license. Anyone may reproduce, distribute, translate and create derivative works of this article (for both commercial and non-commercial purposes), subject to full attribution to the original publication and authors. The full terms of this license may be seen at: http://creativecommons.org/licences/by/4.0/legalcode

Vol. 9(2) 2020, Pg. $158-171$

http://hrmars.com/index.php/pages/detail/IJARPED

JOURNAL HOMEPAGE

Full Terms \& Conditions of access and use can be found at http://hrmars.com/index.php/pages/detail/publication-ethics 


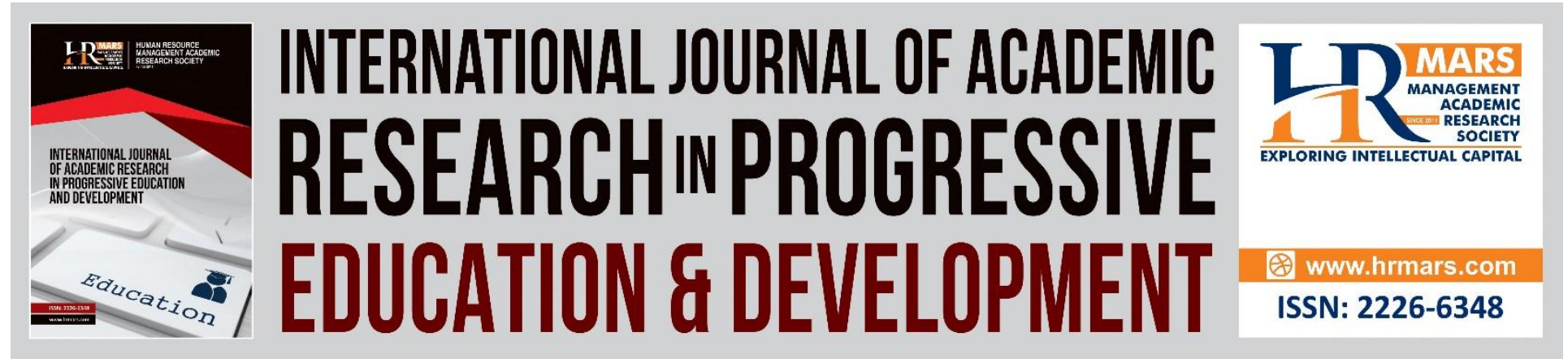

\title{
TPACK Framework Based Research in Mathematical Education: A Systematic Literature Review
}

\author{
Noraidah Othman \& Siti Mistima Maat \\ Faculty of Education, Universiti Kebangsaan Malaysia \\ Email: aida1202@gmail.com, sitimistima@ukm.edu.my
}

\begin{abstract}
This systematic literature review aims to identify the themes of the study on the Technology Pedagogical Content Knowledge (TPACK) framework in mathematics education and the research methods used in the studies. The search for articles published from year 2015 to 2020 was conducted through the Google Scholar electronic database. A total of 30 articles were selected. The results show that researchers are more focused on studying the level and effectiveness of technology integration in mathematical learning. Over $50 \%$ of the research has been done on teachers compared to students and lecturers in the field of mathematics. The findings also show that technology integration in teaching fraction and algebra is the most frequently studied. Qualitative research method is the dominant research methodology used to study the research objectives regarding the TPACK framework, compared to the quantitative method and the mixed method. Limitations and suggestions for further studies are also discussed.
\end{abstract}

Keyword: TPACK, Mathematics Education, In-service, Technology.

\section{Introduction}

Technological advancements contribute to the transformation of education. In this light, the integration of technology in teaching is considered as a responsive and innovative pedagogical tool in $21^{\text {st }}$-century learning (Naidoo, 2014). Ansyari (2015) argued that the use of technology has increased rapidly in the educational environment while Holmgren (2015) reported that the use of technology-based tools has led to a positive growth in teaching. This is due to the inclusion of year-round students from different family backgrounds who each have different intelligence and abilities. Thus, there is a need to change the landscape of traditional education if educators want to prepare students to become successful global citizens (Judd, 2015). Educators should be wise in selecting and using technology-based teaching aids that have the potential to enhance students' interest and achievement in the subject. 
The National Council of Teachers of Mathematics (NCTM, 2008) recognizes that Information and Communication Technology (ICT) is an important tool for communicating mathematical concepts in the 21st century (Mwambene \& Luneta, 2015). Ittigson and Zewe (2003) further stated that technology is important in teaching and learning mathematical cones. ICT improves the way mathematics is taught and enhances students' understanding of basic concepts. Numerous studies have examined the benefits of using ICT in mathematics. Becta (2003) summarized the main benefits of technology integration as it encourages collaboration among students and promotes communication for knowledge sharing. Subsequently, ICT is considered as a teaching tool and it supports constructivist pedagogy by allowing students to explore and build their own understanding of concepts.

Technological Pedagogical and Content Knowledge (TPACK) was introduced more than a decade ago. Pierson (2001) is one of the early works on this framework, and followed by many others proposinga similar concept of technology integration (Angeli \& Valanides, 2005; Koehler \& Mishra, 2005). The term TPACK first came to prominence in 2006 following the seminal work of Mishra and Koehler (2005) detailing the model's construction and guidelines. The TPACK framework was originally called "TPCK" and in 2008, it was changed to TPACK, which is easier to pronounce (Thompson, 2008).

The TPACK framework is built on the concept of Pedagogical Content Knowledge by Shulman (1986). Subsequently, technology knowledge components are integrated into the PCK model. The TPACK framework is depicted in the Venn diagram as shown below. It consists of three main overlapping elements representing pedagogical knowledge (PK), content knowledge (CK), and technology knowledge (TK). The combination of these three types of knowledge has created four additional components, namely pedagogy content knowledge (PCK), technology pedagogical knowledge (TPK), technology content knowledge (TCK), and technology pedagogical content knowledge (TPACK). Each knowledge represented in the TPACK framework is described as follows:

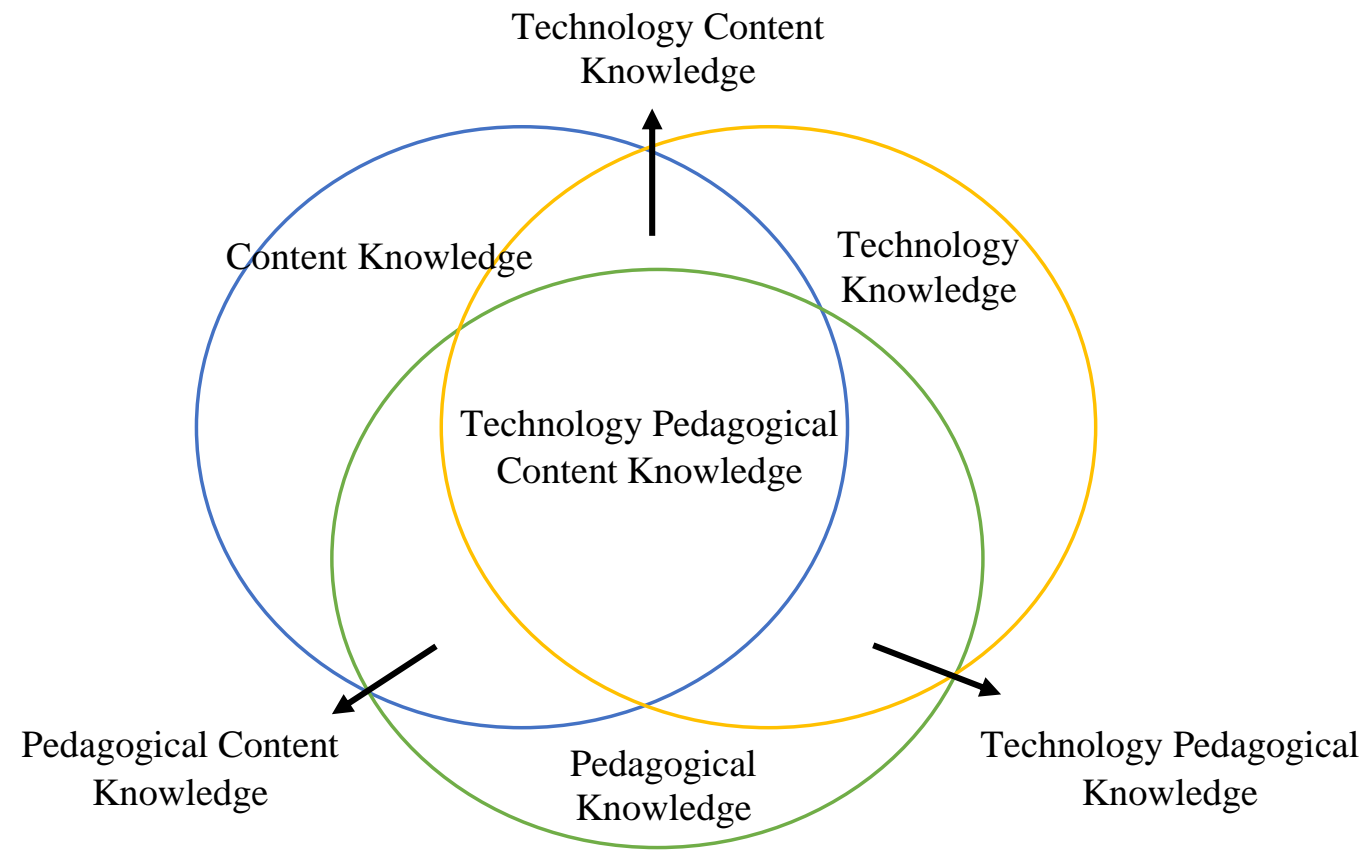


Since the emergence of Technology Pedagogical Content Knowledge (TPACK) frameworks (Mishra \& Koehler, 2006), more than 500 TPACK-based studies, specifically on the integration of knowledge and technology have been implemented and published. The majority of these studies have focused on TPACK's development of future educators (Setiawan, Phillip, \& Isnaeni, 2019). On the other hand, studies on the use of technology by academics in higher education are still lacking (Flavin, 2012). Many international studies have also focused on the development of TPACK for in-service educators (Stoilescu, 2011). However, most of these studies did not focus on the development of TPACK among in-service mathematics academicians (Eng, \& Keong, 2019).

In Malaysia, the Ministry of Education (MOE) has taken the initiative to produce quality educators by utilizing technology to improve the quality of their teaching practices, as explained in the 7th edition of the Malaysian Education Development Plan (PPPM). However, there are still gaps in the educational patterns, especially in mathematics, that need to be studied (Eng, \& Keong, 2019). Thus, this systematic literature review aims to answer the following two research questions:

1. What are the key features of TPACK's framework of research in mathematics education?

2. What research methods have been used to conduct studies on the TPACK framework in mathematics education?

\section{Methodology}

Article search was conducted to find journal articles related to the TPACK framework. The researcher has set several criteria before the search was performed. First, the year of publication of the article, where the articles selected for this study must be published in the last five years (between 2015 and 2020). The second criterion is the database used to search the article and in this case, the Google Scholar database. The third criterion is the keywords or key terms used to find electronic articles in the database. The keywords used are TPACK or TPCK, and mathematics. The use of Boolean operations "AND" and "OR" were used and these keywords should be mentioned in the abstract, keywords, or title of the study. PCK (Pedagogical Content Knowledge) was not included in the article selection. The fourth criterion is that the article must be in English, but not limited to any country of publication. The next criterion is the scope of the study, specifically mathematics education and includes all levels of education, from pre-education to higher education. The sixth criterion is that the participants or respondents of the study must be students or educators who are in the field of teaching mathematics. Studies conducted on prospective educators, pre-service educators, practical educators and others were not included. Seventh criterion is that only empirical studies were selected while meta-analysis studies, literature reviews, concept papers, systematic studies of analysis and thesis / dissertation were not included in the article selection. Finally, after the potential research articles were identified, a further screening process was performed to ensure that all selected articles meet the stated criteria. The Google Scholar database was used to find articles that meet all the criteria. A summary of the search process of the articles is shown in the PRISMA chart below: 


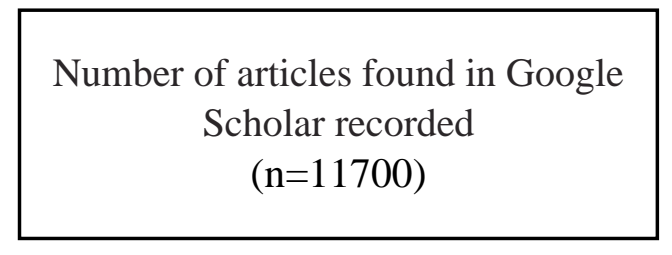

Record being screened $\mathrm{n}=11550$

Full text analyzed based on criteria

$$
\mathrm{n}=43
$$

Full article texts analyzed based

on criteria

$$
\mathrm{n}=30
$$

Full article texts analyzed based

on criteria

$$
\mathrm{n}=30
$$

Record being excluded (studies on

pre-service educator, STEM)

$$
\mathrm{n}=11507
$$

Full texts excluded because of different reasons (dissertation, chapter, not empirical research)

$$
(n=13)
$$

Figure 2: PRISMA Flow Chart

After the in-depth screening process, a total of 30 articles were selected. Each article was summarized in six aspects, (1) the study aspect, (2) the domain of mathematics studied, (3) the country in which the study was conducted, (4) the research design used, (5) the data collection method and (6) educational institutions. Aspects (1) and (2) answer the first research question while the rest answer the second research question. Each article is given a serial number code to facilitate analysis and reference. These data are presented in the form of a Microsoft Excel table. The data were quantitatively analyzed by looking at the frequency of each category. The results of the analysis are then quantitatively compared and contrasted with the data in each category using frequency.

\section{Analysis Results \\ Research Theme}

The analysis begins with a search for similarities and themes differences. Based on the critical analysis carried out on the purpose and questions of research presented in each article, four main research themes were identified, namely (a) identify the relationships among TPACK components, (b) identify the relationship between TPACK components and other variables, (c) identify the extent and impact of the integration of existing and new technologies in mathematics learning, and (d) identify the effectiveness of educators' professional development programs. Table 1 shows the themes identified from previous studies. 
The results showed that two studies examined the ability of TPACK among educators of mathematics subjects, which are Harits, et al., (2019) and Mailizar, and Fan (2020). Studies carried out by Loong (2014) and Hansen, A. et al. (2016) explored teachers' development and knowledge through the TPACK framework. In addition, studies compared the level of development of TPACK among educators based on other variables.

Nine articles share the same research theme, which is the relationships between TPACK components and other variables. The other variables included were belief (Lai, T. L., \& Lin, H. F., 2018), attitude (Esquincalha, \& Abar, 2016; Adulyasas, 2017; Stoilescu, 2015), self-efficacy (Akturk, \& Ozturk, 2018; Kang, \& Jang, 2016), demographics (Ozudogru, \& Ozudogru, 2019), and teaching techniques (Evans, A. et al., 2015).

Mathematics is often considered difficult and tedious by most students. However, the use of technology can encourage collaboration, information sharing, provide quick feedback and increase motivation among students (Gonzalez \& Ruiz, 2017). As such, many articles have been published to identify the effectiveness of existing and new technologies in mathematical learning. Among the technologies used are smart devices (tablets) (Tsouccas, \& Meletiou-Mavrotheris, 2019; Ingram, 2016; Miller, 2018), gaming applications (Evans, et al., 2015), smart boards (Muir, et al., 2016; Cabus, et al., 2017) and existing applications such as Facebook (GreGory, et al., 2016) and GeoGebra (Khalil, et al., 2017; Kirikçilar, \& Yildiz, 2018).

Professional development of educators is now seen as an important factor in enhancing educators' professionalism (Schwarz, \& Kaiser, 2019). Studies conducted by Loong and Herbert, (2018) and Havard, B. et al. (2018) identified the relationship between teacher professional knowledge and student achievement while studies conducted by Loong, and Herbert (2018), Ingram (2016), Martin, et al. (2016), Erduran, and Ince, (2018) and Kang and Jang (2016) focused

on the effectiveness of professional development programs to enhance teachers' skills and knowledge in integrating technology in the classroom. 
Table 1: Themes identified from past studies

\begin{tabular}{|c|c|c|c|c|c|}
\hline Author & $n$ & $\begin{array}{l}\text { Relationship } \\
\text { within TPACK } \\
\text { component }\end{array}$ & $\begin{array}{l}\text { The relationship } \\
\text { between TPACK } \\
\text { components and other } \\
\text { variables }\end{array}$ & $\begin{array}{l}\text { Technology } \\
\text { integration }\end{array}$ & $\begin{array}{l}\text { Professional } \\
\text { Development }\end{array}$ \\
\hline $\begin{array}{l}\text { Lai \& Lin (2018), Esquincalha \& Abar (2016), } \\
\text { Akturk \& Ozturk (2018), Ozudogru \& Ozudogru } \\
\text { (2019), Evans,. et al. (2015). } \\
\text { Adulyasas (2017) }\end{array}$ & 6 & I & I & & \\
\hline $\begin{array}{l}\text { Patahuddin et al. (2016), Muir et al. (2016), } \\
\text { Cabus, et al. (2017), Kirikçilar \& Yildiz (2018), } \\
\text { Miller (2018). } \\
\text { Naidoo (2015), GreGory et al. (2016), Khalil } \\
\text { (2017). }\end{array}$ & 8 & & & I & \\
\hline $\begin{array}{l}\text { Loong \& Herbert (2018), Havard (2018), } \\
\text { Hansen (2016), Martin et al. (2016), Erduran \& } \\
\text { Ince (2018) }\end{array}$ & 5 & & & & l \\
\hline $\begin{array}{l}\text { Loong (2014), Hill \& Uribe-Florez (2019), } \\
\text { Galleto \& Pangilinan (2019), Harits (2019), } \\
\text { Mailizar \& Fan (2020), Wati\& Fitriana (2018), } \\
\text { Hill \& Uribe-Florez (2019). }\end{array}$ & 6 & l & & & \\
\hline Tsouccas \& M eletiou-Mavrotheris (2019). & 1 & & l & / & l \\
\hline Ingram et al. (2016). & 1 & & & l & I \\
\hline Evans et al. (2015). & 1 & I & & l & \\
\hline Kang \& Jang (2016). & 1 & I & & & I \\
\hline Stoilescu (2015). & 1 & & I & & \\
\hline
\end{tabular}


Vol. 9, No. 2, 2020, E-ISSN: 2226-6348 @ 2020 HRMARS

\section{Mathematics domains being studied}

The results show that there are four mathematical domains studied by the previous researchers, namely fractions (Patahuddin et al., 2016; Evanset al., 2015; Hansen et al., 2016), geometry (Kirikçilar \& Yildiz 2018; Kang \& Jang 2016), algebra (Kirikc; Ilar\& Yildiz2018; Evanset al., 2015; Khalilet al., 2017) and linear equations (Wati \& Fitriana, 2018). Furthermore, researchers do not specifically specify mathematical domains.

\section{Research Context}

\section{Countries where Research is Done}

Table 2: Countries where studies were conducted

\begin{tabular}{|c|c|c|}
\hline Country & $\begin{array}{l}\text { Number of } \\
\text { Studies }\end{array}$ & Article \\
\hline Taiwan & 1 & Lai \& Lin (2018) \\
\hline Indonesia & 5 & $\begin{array}{l}\text { Patahuddin (2016), Loong (2014), Haritset al. (2019), } \\
\text { Mailizar\& Fan (2020), Wati \& Fitriana (2018) }\end{array}$ \\
\hline Cyprus & 1 & Tsouccas \& Meletiou-Mavrotheris (2019) \\
\hline Brazil & 1 & Esquincalha \& Abar (2016) \\
\hline Australia & 2 & Loong \& Herbert, S. (2018), Muir (2016). \\
\hline Amsterdam & 1 & Cabus et al. (2017) \\
\hline Turkey & 3 & $\begin{array}{l}\text { Akturk, \& Ozturk, H. S. (2018), Ozudogru, \& Ozudogru } \\
\text { (2019), Erduran \& Ince (2018). }\end{array}$ \\
\hline Romania & 1 & Kirikçilar \& Yildiz (2018) \\
\hline Canada & 3 & Evans et al. (2015), Miller (2018), Stoilescu (2015). \\
\hline $\begin{array}{l}\text { United States of } \\
\text { America }\end{array}$ & 5 & $\begin{array}{l}\text { Havard, (2018), Hill \& Uribe-Florez (2019), Martinet al. } \\
\text { (2016), GreGory (2016) }\end{array}$ \\
\hline New Zealand & 1 & Ingram (2016) \\
\hline Thailand & 1 & Adulyasas (2017). \\
\hline Africa & 1 & Naidoo (2015) \\
\hline Phillipines & 1 & Galleto \& Pangilinan (2019) \\
\hline Korea & 1 & Kang, S., \& Jang, M. (2016) \\
\hline Pakistan & 1 & Khalil et al. (2017) \\
\hline Europe & 1 & Hansen et al. (2016) \\
\hline
\end{tabular}

Table 2 presents an overview of the research location and it is clear that most of the studies are from Indonesia and the United States with five articles each. Many Asian and European countries have contributed articles using the TPACK framework. 
INTERNATIONAL JOURNAL OF ACADEMIC RESEARCH IN PROGRESSIVE EDUCATION AND

DEVELOPMENT

Vol. 9, No. 2, 2020, E-ISSN: 2226-6348 @ 2020 HRMARS

\section{Research Participants and Educational Institution}

Table 3: Research participants and educational institution

\begin{tabular}{|c|c|c|c|c|}
\hline Participants & Students & Teacher & Lecturer & $\mathrm{N}$ \\
\hline Pre School & & Miller, T. (2018) & & \\
\hline $\begin{array}{l}\text { Primary } \\
\text { School }\end{array}$ & $\begin{array}{l}\text { Khalil, M. et } \\
\text { al. (2017) }\end{array}$ & $\begin{array}{l}\text { Tsouccas, L. F., \& Meletiou- } \\
\text { Mavrotheris, M. (2019), Loong, E. Y. K., } \\
\text { \& Herbert, S. (2018), Muir, T., et al. } \\
\text { (2016), Hansen, A. et al. (2016), Martin, } \\
\text { C. S. et al. (2016), Harits, M., et al. } \\
\text { (2019) }\end{array}$ & & 7 \\
\hline $\begin{array}{l}\text { Secondary } \\
\text { School }\end{array}$ & & $\begin{array}{l}\text { Lai, T. L., \& Lin, H. F. (2018), } \\
\text { Patahuddin, S. M. et al. (2016), } \\
\text { Esquincalha, A. D. C., \& Abar, C. A. } \\
\text { (2016), Cabus, S. J. et al. (2017), Akturk, } \\
\text { A. O., \& Ozturk, H. S. (2018), Kirikçilar, } \\
\text { R. G., \& Yildiz, A. (2018), Ozudogru, M., } \\
\text { \& Ozudogru, F. (2019), Evans, M. A. et } \\
\text { al. (2015), Havard, B. et al. (2018), } \\
\text { Loong, E. Y. K. (2014), Evans, M. A. et } \\
\text { al. (2015), Adulyasas, L. (2017), Hill, J. } \\
\text { E., \& Uribe-Florez, L. (2019), Mailizar, } \\
\text { M., \& Fan, L. (2020), Wati, S., \& } \\
\text { Fitriana, L. (2018), Erduran, A., \& Ince, } \\
\text { B. (2018), Kang, S., \& Jang, M. (2016), } \\
\text { Stoilescu, D. (2015). }\end{array}$ & & 18 \\
\hline $\begin{array}{l}\text { Higher } \\
\text { Education }\end{array}$ & $\begin{array}{l}\text { Naidoo, J. } \\
\text { (2015), } \\
\text { Galleto, P. G., } \\
\text { \& Pangilinan, } \\
\text { N. B. (2019) }\end{array}$ & & $\begin{array}{l}\text { GreGory, P. L. } \\
\text { et al. (2016). }\end{array}$ & 3 \\
\hline $\mathrm{N}$ & 3 & 25 & 1 & 29 \\
\hline
\end{tabular}

Mathematics has been introduced to students since the beginning of school and the learning continued through higher education. Table 3 shows the participants and educational institutions involved in the study using the TPACK framework. A total of 25 articles were conducted on teachers; of which 18 were conducted on secondary teachers; six were on primary and pre-school teachers. Only one study based on the TPACK framework was tested on lecturers from institutions of higher learning. This is consistent with the observation by $\mathrm{Wu}, \mathrm{Hu}, \mathrm{Gu}, \& \mathrm{Lim}$, (2016) that studies on lecturers are limited. They added that although lecturers typically receive more academic training and have higher academic degrees, this does not mean that the subject's expertise gives them the ability to teach and integrate the technology learned in teaching. 
INTERNATIONAL JOURNAL OF ACADEMIC RESEARCH IN PROGRESSIVE EDUCATION AND

DEVELOPMENT

Vol. 9, No. 2, 2020, E-ISSN: 2226-6348@ 2020 HRMARS

\section{Research Design}

Table 4: Research design and research method for each article

\begin{tabular}{|c|c|c|c|c|c|c|c|c|}
\hline \multirow[t]{2}{*}{ Article } & \multicolumn{4}{|c|}{ Research Design } & \multicolumn{4}{|c|}{ Data Collection Method } \\
\hline & $\begin{array}{c}\text { Qua } \\
\text { ntita } \\
\text { tive }\end{array}$ & $\begin{array}{l}\text { Quali } \\
\text { tativ } \\
\mathrm{e}\end{array}$ & Mix & $\begin{array}{c}\text { Ques } \\
\text { tionn } \\
\text { aire }\end{array}$ & $\begin{array}{l}\text { Pre- } \\
\text { Test }\end{array}$ & $\begin{array}{c}\text { Obse } \\
\text { rvati } \\
\text { on }\end{array}$ & $\begin{array}{l}\text { Inter } \\
\text { view }\end{array}$ & $\begin{array}{l}\text { Docu } \\
\text { ment } \\
\text { Anal } \\
\text { ysis }\end{array}$ \\
\hline Lai \& Lin (2018) & I & & & I & & & & \\
\hline Patahuddin. et al. (2016) & & I & & & & & & \\
\hline $\begin{array}{l}\text { Tsouccas \& Meletiou- } \\
\text { Mavrotheris }\end{array}$ & & & I & I & & & I & \\
\hline Esquincalha \& Abar (2016) & & I & & & & I & & \\
\hline Loong \& Herbert (2018) & & & & & & & I & \\
\hline Muir et al. (2016) & & & & & & I & I & I \\
\hline Cabuset al. (2017) & & I & & & I & I & & \\
\hline Akturk \& Ozturk (2018) & I & & & I & & & & \\
\hline Kirikçilar \& Yildiz (2018) & & & l & & & / & l & \\
\hline Ozudogru \& Ozudogru (2019 & & & & & & & & \\
\hline Evans et al. (2015) & & & l & & l & l & l & \\
\hline Havard et al. (2018) & I & & & I & & & & I \\
\hline Ingram et al. (2016) & & I & & & & & I & \\
\hline Loong (2014) & & & I & I & & I & I & \\
\hline Hansen (2016) & & I & & & & I & I & I \\
\hline Miller (2018) & & & I & & I & I & I & \\
\hline Evans et al. (2015). & & I & & & I & & I & \\
\hline Adulyasas (2017) & I & & & I & & & & \\
\hline Hill \& Uribe-Florez (2019) & & & I & I & & & I & \\
\hline Naidoo (2015) & & I & & I & & & I & \\
\hline Martinet al. (2016) & & & I & & I & & & I \\
\hline Galleto \& Pangilinan (2019) & I & & & I & & & & \\
\hline GreGory et al. (2016) & l & & & l & & & & \\
\hline Harits et al. (2019) & & I & & & & I & I & \\
\hline Mailizar \& Fan (2020) & I & & & I & & & & \\
\hline Wati\& Fitriana (2018) & & & I & I & & & I & \\
\hline Erduran \& Ince (2018) & & I & & & & I & I & I \\
\hline Kang\& Jang (2016) & I & & & I & & & & \\
\hline Stoilescu (2015) & & I & & & & I & I & I \\
\hline Khalil et al. (2017) & & l & & & l & & & \\
\hline & 8 & 11 & 8 & 13 & 6 & 11 & 16 & 6 \\
\hline
\end{tabular}


Research methods refer to how researchers obtain information to achieve the research goal (Rich \& Elster, 2019). The study method was categorized into two, namely study design and data collection method. There are three research methods namely quantitative, qualitative and mixed methods. Methods of data collection include questionnaires, pre- and post-tests, interviews, observations (for example, observations during learning sessions, videos) and document analysis (including lesson plans, student assessment, transcripts and others).

The results showed 11 articles using qualitative methods compared to eight articles for both quantitative and mixed methods. Meanwhile, the interview was most widely used in the study of 16 articles. Many researchers have tested the validity and reliability of the TPACK questionnaire (Schmidt, 2009; Elas, Majid \& Suthagar, 2019; Sahin, 2011). Therefore, researchers such as Tsouccas, \& Meletiou-Mavrotheris, (2019); Adulyasas (2017); Hill \& Uribe (2019); Galleto \& Pangilinan (2019); Wati \& Fitriana (2018); and Kang\& Jang (2016) have adopted the TPACK questionnaire in their study. However, there is also a TPACK questionnaire that has been modified into a TPACK-MT which focuses more on mathematics education, adopted by Patahuddin, et al. (2016); Mailizar and Fan (2020) in their study.

\section{Conclusion}

This systematic literature review is based on the empirical study of content pedagogical technology (TPACK) knowledge in mathematics education. Previous studies published in the Google Scholar database have been selected in various screening processes. A total of 30 articles were selected and analyzed. Research questions for this systematic literature review have been identified as (1) What are the main features of the study related to the TPACK framework in mathematics education? (2) What research methods have been used to conduct studies on the TPACK framework in mathematics education?

For the first research question, the main theme of the empirical studies on TPACK framework was identified. The findings show that there are four main themes, namely (a) identify the relationships among TPACK components, (b) identify the relationship between TPACK components and other variables, (c) identify the effects of integrating existing and new technologies in mathematical learning and (d) identify the effectiveness of educators' professional development programs. Researchers are more focused on studying the level and effectiveness of technology integration in mathematical learning. Studies have also been conducted to look at the relationship between elements in the TPACK framework with other variables such as demographics, perceptions, self-efficacy, attitudes and beliefs.

Next, the research methodology used to conduct TPACK framework studies in mathematics education has also been identified. There are many studies conducted in Asia and continental Europe based on the TPACK framework. These studies are more often done on mathematics teachers than towards students and lecturers. Researchers are more focused on mathematics teachers in high school. The domain of mathematics is widely studied in education. However, the integration of technologies based on fractional and algebraic topics has also been studied. This is because the use of technology in these topics makes it easier for teachers to increase student interest and achievement (Evans et al., 2015; Patahuddin, 2016). The qualitative research method is dominant over the quantitative method and the mixed method is used to study the research objectives based on the TPACK framework. 
Nevertheless, this systematic literature review has some limitations. Some of the criteria set out in this article are based on the researcher's conclusions. Articles selected primarily from Google Scholar may not be subject to peer review or expert review. The articles selected were only articles in English, which may have influenced the findings that most articles were published from Europe.

This systematic literature review analyzes only 30 related articles. Therefore, future studies need to confirm the generalizability of the findings in this study with a broader domain. These studies in the broader context may indicate greater validity in specific domains such as algebra, linear equations, indexes or logarithms. Some future directions that can be considered are to develop meta-analysis of the related TPACK framework in mathematics education as well as by providing integrative view of TPACK component in various fields. An imperative strategy of TPACK in teaching mathematics is also required in order to develop technology knowledge roadmap for teachers.

\section{References}

Adulyasas, L. (2017). Measuring and Factors Influencing Mathematics Teachers' Technological Pedagogical and Content Knowledge (TPACK) In Three Southernmost Provinces, Thailand. In AIP Conference Proceedings AIP Publishing. https://doi.org/10.1063/1.4995159

Akturk, A. O., \& Ozturk, H. S. (2018). Teachers' TPACK Levels and Students' Self-efficacy as Predictors of Students' Academic Achievement. International Journal of Research in Education and Science, 5(1), 283-294.

Angeli, C., \& Valanides, N. (2005). Preservice Elementary Teachers as Information and Communication Technology Designers: An Instructional Systems Design Model Based on an Expanded View of Pedagogical Content Knowledge. Journal of Computer Assisted Learning, 21(4), 292-302. https://doi.org/10.1111/j.1365-2729.2005.00135.x

Ansyari, M. F. (2015). Designing and Evaluating a Professional Development Programme for Basic Technology Integration in English as A Foreign Language (EFL) Classrooms. Australasian Journal of Educational Technology, 31(6). https://doi.org/10.14742/ajet.1675

Elas, N. I. B., Majid, F. B. A., \& Suthagar, A. (2019). Development of Technological Pedagogical Content Knowledge (TPACK) For English Teachers: The Validity and Reliability. International Journal of Emerging Technologies in Learning (iJET), 14(20), 18-33. 10.3991/ijet. v14i20.11456

Eng, C. Y., \& Keong, T. C. (2019). Pengetahuan Teknologi Pedagogi Kandungan di Malaysia: Satu Kajian Meta Analisis. Journal of ICT in Education, 1, 86-95.

Erduran, A., \& Ince, B. https://doi.org/ (2018). Identifying Mathematics Teachers' Difficulties in Technology Integration In Terms Of Technological Pedagogical Content Knowledge (TPCK). International Journal of Research in Education and Science, 4(2), 555-576.

Esquincalha, A. D. C., \& Abar, C. A. (2016). Knowledge Revealed by Tutors in Discussion Forums With Maths Teachers. Teaching Mathematics and Its Applications: International Journal of the IMA, 35(2), 65-73. https://doi.org/ 10.1093/teamat/hrw002

Flavin, M. (2012). Disruptive technologies in higher education. Research in Learning Technology, 20, 102 - 111. https://doi.org/10.3402/rlt.v20i0.19184 
INTERNATIONAL JOURNAL OF ACADEMIC RESEARCH IN PROGRESSIVE EDUCATION AND

DEVELOPMENT

Vol. 9, No. 2, 2020, E-ISSN: 2226-6348 @ 2020 HRMARS

Galleto, P. G., \& Pangilinan, N. B. (2019). Diagnosing Technological Pedagogical Content Knowledge Landscape: The Case of the Mathematics Teachers in Government-Funded University. International Journal of Scientific Research and Education, 6(7).

Gonzalez, M. J. \& Ruiz, I. G. (2017). Behavioural Intention and Pre-Service Mathematics Teachers' Technological Pedagogical Content Knowledge. Journal of Mathematics Science and Technology Education 13(3): 601-320. https://doi.org/10.12973/eurasia.2017.00635a

Hill, J. E., \& Uribe-Florez, L. (2019). Understanding Secondary School Teachers' TPACK and Technology Implementation in Mathematics Classrooms. International Journal of Technology in Education, 3(1), 1-13.

Kang, S., \& Jang, M. (2016). On Secondary Mathematics Teachers' Technology Integration SelfEfficacy. The Mathematical Education, 55(4), 523-538. https://doi.org/10.7468/mathedu.2016.55.4.523

Kaya, V. H., \& Elster, D. (2019). Environmental Science, Technology, Engineering, and Mathematics Pedagogical Content Knowledge: Teachers' Professional Development as Environmental Science, Technology, Engineering, and Mathematics Literate Individuals in the Light of Experts' Opinions. Science Education International, 30(1), 11-20.

Kirikçilar, R. G., \& Yildiz, A. (2018). Technological Pedagogical Content Knowledge (TPACK) Craft: Utilization of the TPACK When Designing the GeoGebra Activities. Acta Didactica Napocensia, 11(1), 101-116.

Koehler, M. J., \& Mishra, P. (2005). Teachers Learning Technology by Design. Journal of Computing in Teacher Education, 21(3), 94-102.

Lai, T. L., \& Lin, H. F. (2018). An Investigation of The Relationship of Beliefs, Values and Technological Pedagogical Content Knowledge Among Teachers. Technology, Pedagogy and Education, 27(4), 445-458. https://doi.org/10.1080/1475939X.2018.1496137

Loong, E. Y. K. (2014). Using the Internet in High School Mathematics. Journal on Mathematics Education, 5(2), 108-126.

Loong, E. Y. K., \& Herbert, S. (2018). Primary School Teachers' Use of Digital Technology in Mathematics: The Complexities. Mathematics Education Research Journal, 30(4), 475498.https://doi.org/10.30935/cet.512515

Mailizar, M., \& Fan, L. (2020). Indonesian Teachers' Knowledge of ICT and the Use of ICT in Secondary Mathematics Teaching. EURASIA Journal of Mathematics, Science and Technology Education, 16(1), 1-13. https://doi.org/10.30935/cet.512515

Miller, T. (2018). Developing Numeracy Skills Using Interactive Technology in A Play-Based Learning Environment. IJ STEM Ed 5, 39. https://doi.org/10.1186/s40594-018-0135-2

Naidoo, J. (2015). The Use of Technology Based Tools in Mathematics Teaching at One University in South Africa. International Journal of Educational Sciences, 10(3), 410-418.

Ozudogru, M., \& Ozudogru, F. (2019). Technological Pedagogical Content Knowledge of Mathematics Teachers and The Effect of Demographic Variables. Contemporary Educational Technology, 10(1), 1-24. https://doi.org/10.30935/cet.512515

Pierson, M. E. (2001). Technology Integration Practice as A Function of Pedagogical Expertise. Journal of Research on Computing in Education, 33(4), 413-430. https://doi.org/10.1080/08886504.2001.10782325 
INTERNATIONAL JOURNAL OF ACADEMIC RESEARCH IN PROGRESSIVE EDUCATION AND

DEVELOPMENT

Vol. 9, No. 2, 2020, E-ISSN: 2226-6348 @ 2020 HRMARS

Sahin, I. (2011). Development of Survey of Technological Pedagogical and Content Knowledge (TPACK). Turkish Online Journal of Educational Technology-TOJET, 10(1), 97-105.

Schmidt, D. A., Baran, E., Thompson, A. D., Mishra, P., Koehler, M. J., \& Shin, T. S. (2009). Technological Pedagogical Content Knowledge (TPACK) The Development and Validation of an Assessment Instrument for Preservice Teachers. Journal of research on Technology in Education, 42(2), 123-149.

https://doi.org/10.1080/15391523.2009.10782544

Schwarz, B., \& Kaiser, G. (2019). The Professional Development of Mathematics Teachers. In Compendium for Early Career Researchers in Mathematics Education (pp. 325-343). Springer, Cham. https://doi.org/10.1080/15391523.2009.10782544

Setiawan, H., Phillipson, S., \& Isnaeni, W. (2019). Current Trends in TPACK Research in Science Education: A Systematic Review of Literature from 2011 To 2017. In Journal of Physics: Conference Series, 1317(1). https://doi.org/10.1088/1742-6596/1317/1/012213

Shulman, L. S. (1986). Those Who Understand: Knowledge Growth in Teaching. Educational Researcher, 15(2), 4-14.: https://doi.org/10.1088/1742-6596/1317/1/012213

Stoilescu, D. (2015). A Critical Examination of The Technological Pedagogical Content Knowledge Framework: Secondary School Mathematics Teachers Integrating Technology. Journal of Educational Computing Research, 52(4), 514-547. https://doi.org/10.1177\%2F0735633115572285

Thompson, A. D. (2008). Breaking News: TPCK Becomes TPACK! Journal of Computing In Teacher Education, 24(2), 2007-2008

Tsouccas, L. F., \& Meletiou-Mavrotheris, M. (2019). Enhancing In-Service Primary Teachers' Technological, Pedagogical and Content Knowledge on Mobile Mathematics Learning. International Journal of Mobile and Blended Learning (IJMBL), 11(3), 1-18. https://doi.org/10.4018/IJMBL.2019070101

Wati, S., \& Fitriana, L. (2018). Technological Pedagogical Content Knowledge of Junior High School Mathematics Teachers in Teaching Linear Equation. In Journal of Physics: Conference Series, 1008 (1)

Wu, B., Hu, Y., Gu, X., \& Lim, C. P. (2016). Professional Development of New Higher Education Teachers with Information and Communication Technology in Shanghai: A Kirkpatrick's Evaluation Approach. Journal of Educational Computing Research, 54(4), 531-562. https://doi.org/10.1177\%2F0735633115621922 